\title{
Are we becoming gadgets? Social capital in the era of social networking
}

$M K I N G L E^{1}$

\begin{abstract}
Social capital is partially predicated on the levels of trust obtaining between institutions and between members of society. As such it is a vital ingredient in the 'glue' which holds society together and which facilitates contractual economic activity. Recent technological advances, and the concomitant ascendancy of social networking, have radically reconfigured the environment in which social capital is generated, and the social sciences have some way to go fully to digest these new developments. This article surveys the meteoric rise of the 'technium' in the social imaginary and delineates some of the reservations current commentators have about the next 'singularity' to succeed the Internet. The discussion includes a brief account of the philosophy behind the objectification of the human. It also speculates about the consequences of paradigm shifts in modes of relating for the formation of social capital in the future.
\end{abstract}

Keywords: social capital; technium; social networking; Facebook; singularity; commodification

Disciplines: Sociology; psychology; philosophy; communications; development studies; human geography; information technology

\section{Introduction}

This article takes as its inspiration Jaron Lanier's (2010) seminal polemic entitled You are not a gadget which, coming as it does from one of the foremost pioneers of 'virtual reality', warrants serious consideration.

The essay provides a contextual elucidation of the notion of 'social capital' before proceeding to describe what is meant by the rise of 'the technium'. It is argued that just as society is changing in response to technology, so too humans are being modified by their technologies, and this in ways of which most are quite unaware. Social isolation, which many scholars perceive as being one of the more insidious concomitants of social networking, is then examined within the contexts of human beings being commodified as saleable datasets, and what many fear is a growing tendency to treat humans as mere things.

The concept of 'convergent evolution', whereby humans and their technologies become, to all intents and purposes, indistinguishable from one another, is then analysed. It is contended that humankind is indeed on the cusp of a new 'singularity' whereby social intercourse as we

1. Dr. Mark K. Ingle is a research associate at the Centre for Development Support (CDS), University of the Free State, Bloemfontein, 9300, South Africa. Email: cdsfreestate@intekom.co.za 
have experienced it hitherto will be revolutionized and reconfigured to accommodate the dictates of new technological advances.

Lanier's (2010) fears about 'cybernetic totalism' and 'standardised presences' are introduced within the ambit of social networking to illustrate just how far the technologically driven reinvention of modern society has advanced. The underlying question is the degree to which humankind and human society is being shaped by devices of its own making. Whatever the answer to this conundrum may be, and whatever the impacts of the new technium on social capital formation, the consequences for society are most certainly going to be both radical and profound.

\section{Social capital}

The first overt mention of 'social capital' appears to date from 1916 and was broached in a rural context. At issue was the notion of community involvement being a necessary condition for quality schooling. Because, according to Robert Putnam (2000:19), this remarkably astute formulation "anticipated virtually all the crucial elements in later interpretations" it is reproduced here in full. Following L.J. Hanifan, a supervisor of rural schools in America, social capital involved:

Those tangible substances [that] count for most in the daily lives of people: namely good will, fellowship, sympathy, and social intercourse among the individuals and families who make up a social unit... The individual is helpless socially, if left to himself... If he comes into contact with his neighbour, and they with other neighbours, there will be an accumulation of social capital, which may immediately satisfy his social needs and which may bear a social potentiality sufficient to the substantial improvement of living conditions in the whole community. The community as a whole will benefit by the coopperation of all its parts, while the individual will find in his associations the advantages of the help, the sympathy, and the fellowship of his neighbours.

In expanding on Hanifan's account, Putnam (2000:19) says that:

The core idea of social capital theory is that social networks have value... [and] affect the productivity of individuals and groups... social capital refers to connections among individuals - social networks and the norms of reciprocity and trustworthiness that arise from them. In that sense social capital is closely related to what some have called 'civic virtue'. The difference is that 'social capital' calls attention to the fact that civic virtue is most porverful when embedded in a dense network of reciprocal social relations.

Carlson (2010:195) adds a further dimension to the concept by construing it as "reputation" such that individuals may come to "accrue social capital" by virtue of what they do.

Although according to Willis (2005:110) "social capital is a highly-contested concept", it is not the intention here to problematise it unnecessarily and the World Bank's formulation which it adopted "as part of the neo-liberal agenda" will suffice for present purposes. The World Bank sees social capital as "the informal rules, norms and long-term relationships that facilitate co-ordinated action and enable people to undertake co-operative ventures for mutual advantage" (Willis, 2005:111). The applicability of social capital to the business environment, in this interpretation, is obvious.

Putnam distinguishes between two major variants of social capital namely bonding and bridging. Bonding is typified by exclusivity where there is normally an element of membership involved, either tacit or overt. It is the 'one of us' syndrome. Those "networks that are 
outward looking and encompass people across diverse social cleavages" and that strive towards inclusivity (for example charismatic church organisations) represent the bridging type of social capital (Putnam, 2000:22). These two characterisations are not mutually exclusive and an entity may exhibit strains of both variants as for example with an Internet chat group which "may bridge across geography, gender, age and religion, while being tightly homogenous in education and ideology" (Putnam, 2000:23). It is of the essence, in evaluating social capital, to appreciate that it is value-neutral - it can be used for good or ill - and that it frequently exhibits 'externalities' that affect the wider community, so that not all the costs and benefits of social connections accrue to the person making the contact" (Putnam, 2000:20).

Following Sen (2006:2), "An identity with others in the same social community can make the lives of all go much better in that community; a sense of belonging to a community is thus seen as a resource - like capital". But as Sen in his study of the links between identity and violence proceeds to point out, "a sense of identity can firmly exclude many people even as it warmly embraces others". This "dark side" of social capital (Putnam, 2000:250) was interestingly enough explored by the social critic and novelist Sinclair Lewis (1922) as early as 1922 in his account of 'boosterism' in a mid-west American town although Lewis did not actually use the term 'social capital'.

Keeley (2007:116) maintains that social capital is even more difficult to measure directly than is human capital because the concept "is still in its infancy" (although see Grootaert, Narayan, Nyhan-Jones \& Woolcock, 2004 for the World Bank's view that it is a well-institutionalised construct which is measurable).

\section{The rise of the technium}

Massive social movements are occurring in the slipstream of technological advances that are moving with extraordinary speed (Kelly, 2010; Bohler-Muller \& van der Merwe, 2011; Essoungou, 2011). Putnam and Feldman's (2003) observations about the effect of the Internet on social capital now read as quaintly affecting just 10 years after publication. There is something almost antiquarian too about Putnam's (2000) repeated invocation of the term "computer-mediated communication". Sherry Turkle $(2011: 16,310)$ for example reports that in January 2010 the 'average' American teenager was sending and receiving around 6500 text messages a month yet in the 500-odd pages of Putnam's seminal exposition of social capital, Bowling Alone, there is but a single mention of cellphones (Putnam, 2000:166) and no mention whatever in its 2003 sequel, Better Together (Putnam \& Feldstein, 2003). This is not to disparage these scholars. Perhaps they could not have guessed at what was on the horison and they do make it very clear that they speak advisedly when speculating about the impact of technology on social capital. But it is to say that substantial portions of the social science literature are being rendered otiose because the world has moved on to a different space.

Since 2003 the world has seen so-called web 2.0 'killer apps', Skype, eBay, YouTube, Facebook, Twitter, PayPal, Second Life and a host of others combine in what some commentators view as a development which will culminate in another 'singularity' (Carlson, 2010; Kelly, 2010). An earlier singularity, according to Barlow (quoted in Putnam, 2000:172) although he does not actually use the word, was the advent of the Internet itself: "We are in the middle of the most transforming technological event since the capture of fire". A singularity is a convergence of processes which results in an utterly changed world which can never revert to its former state. For Turkle (2011:25) the singularity is a "notion that has 
migrated from science fiction to engineering... at the singularity we may merge with the robotic and achieve immortality... [it is] technological rapture”.

Society is changing in response to technology and so are humans, in more ways perhaps than is generally realised (Carr, 2010). The economic and social sciences, ungeared as their scholarly apparatus is to cope with such rapid change, find themselves perpetually having to 'catch up' in trying to 'metabolise' the implications of the new 'technium', Kelly's term for the entire technological realm. Turkle's (2011) Alone Together - a clever play on Putnam's titles Bowling Alone and Better Together - was in important geo-political respects obsolete even while it was being launched. Advances in biotechnology, nanotechnology and the neurosciences are keeping abreast of the information technology juggernaut with the result that the kaleidoscopic networks that constitute the essence of social capital, and the various 'knowledges' on which these networks feed, are being reconfigured almost before one's eyes. The 'technium' really has assumed a life of its own (Kelly, 2010) much to many observers' deep consternation (Carr, 2010; Lanier, 2010; Turkle, 2011).

Putnam (2000:180) averred that: "The most important question is not what the Internet will do to us, but what we will do with it". Ten years later and that question has been very firmly turned on its head. Turkle (2011:19) quotes Winston Churchill - "We shape our buildings and then they shape us". At issue now is what the Internet has already done with us and what it continues to do with us in its latest incarnations. There is a pronounced uneasiness as to whether this accelerated technological progress obligingly translates into buman progress and this is discussed at greater length in a later section.

\section{Alone together?}

As already intimated there are many scholars who have serious misgivings about the turn information technology has taken and most especially about its 'social networking' dimension. Although they feel something is going wrong no one can quite put their finger on what exactly it is.

Richard Florida (2010:6) maintains that: "Technological innovation leads to new forms of infrastructure, which lead to revolutions in where and how we live and work". Watson's (2010:125) assertion that: "The very technologies that are bringing us closer together on one level are tearing us apart on another. E-mail, SMS, social networks, and the like are addictive attention eaters" can probably be regarded as a truism. Turkle's title Alone Together suggests much the same thinking. To discuss 'social capital' but confine oneself to the sociologicallydenominated frames of reference within which the concept was originally formulated (Putnam, 2000) is rather like trying to analyse the impact of technology on society while bracketing out Information Technology (IT). To take but one example - the meteoric ascendancy of 'social networking' is unprecedented as a cultural phenomenon and must begin to be factored into assessments of social capital - arguably as its chief determinant, at least in the developed world. As Collier (2010:235) remarks: "There are supposedly only six degrees of separation between any two people on earth. For the first time in history we have a technology that can span those degrees of separation". What might this mean for the social capital generated by the users of these novel technologies?

\section{Humans as objects}

In her manifesto on the value of the humanities for fostering democracies and healthy civic engagement, Nussbaum (2010) returns repeatedly to the warning that an education system 
that is solely concerned with maximising efficiency and boosting economic growth risks turning people into 'things'. She writes:

We seem to be forgetting about the soul, about what it is for thought to open out of the soul and connect a person to the world in a rich, subtle and complicated manner; about what it is to approach another person as a soul, rather than as a mere useful instrument or an obstacle to one's plans; about what it is to talk as someone who has a soul to someone else whom one sees as similarly deep and complex (2010:6)

Nussbaum is not necessarily using 'soul' in a religious sense but rather as those faculties betokening what it is to be distinctively human. Precisely the same preoccupations are expressed by the 'creativity philosopher' Jaron Lanier (2010:75) in his account of the "spiritual failure" and fragmentation of human being occasioned by "the current dominant ideology of the digital world". This he argues tends to "undervalue humans" and encourage "the ubiquitous invocations of anonymity and crowd identity". Turkle, a seasoned professor of "social studies of science" at the Massachusetts Institute of Technology (MIT), now says her initial optimism about the "freedom of online identity" is "long gone". She says that we have "invented ways of being with people that turn them into something close to objects" despite a large scale 2007 study by the University of Michigan that claimed that "Facebook users had more social capital than abstainers" (Lehrer, 2011). Perhaps this form of capital is coming to accrue at too high a cost - the cost of our humanity? These anxieties are by no means confined to Lanier, Nussbaum and Turkle but are part of a rising tide of disquiet about the long term effects of telecommunications advances (Smith, 2010; Watson, 2010; Halpern, 2014).

For the existentialist philosopher Martin Heidegger we do not approach the many things that make up our world with studied indifference. "Our primary way of relating to the world is by practical concernful activity [praxis], and not by disinterested observation” (Waterhouse, 1981:71). The Greek word for 'things', encountered in the course of praxis, is pragmata and as the word suggests it has a 'pragmatic' connotation. 'Things' in our engagement with our environment are not 'just there' and not 'just things'. For Heidegger, in his 1926 masterpiece Being and Time, things are always encountered "in concern" and can therefore be better understood as "equipment" - either potential or actual (Heidegger, 1962:96-97). Lest this be thought rather a peculiar notion it should be noted that it finds support with the concept of "affordances" developed within the discipline of neuropsychology (Blakeslee \& Blakeslee, 2007:105-108). 'Afford' should here be understood in the sense of the possibilities some thing affords one, the possibilities inherent within it. According to this theory the brain apprehends things "in terms of how you think you can interact with what you see. You see affordances... [via] higher visual processing... when you see a chair, you 'see' its sittability, its stand-upon-to-reach-the-high-shelf-ability..." and so forth. These are "action-based" concepts automatically evoked by apprehension. We are therefore immersed in a world of equipment - the "ready to hand" in Heidegger's terminology. The obvious question which then arises is "what can I do with the ready-to-hand?". This is a legitimate question from the practical, scientific perspective when addressed to the particular but less so from the philosophical perspective of, say, 'thingness' as such - that is the universal aspect. Here, in the spirit of a lecture delivered by Heidegger (1959:12) in 1935, we could also fruitfully ask ourselves, "what might it do with me?". The situation is greatly complicated when it comes to other people. Are they also equipment? Or, to turn the question on its head, are we their equipment? Presumably yes - to the degree that we can be constituted by them as pragmata. This is something Jean-Paul Sartre (1943) deals with at length in his monumental Being and 
Nothingness. It should be borne in mind that this work was written during an extremely grim period in history when people (not to mention soldiers) were routinely being treated as subhuman 'things' (see for example Beevor, 1999). As is well known "people behave badly when the human beings over whom they have power are dehumanized... [and] much worse when the 'other' is portrayed... as bearing only a number rather than a name" (Nussbaum, 2010:44).

Sartre distinguishes between three modes of being for humans - Being-in-itself; Being-foritself; and Being-for-others. These distinctions could be useful for analysing interactions within the 'social networking' arena:
Human beings... are the kinds of being who exist for-themselves. Yet being-for-itself is a fundamentally reflexive category: only the entity whose being it is can witness it. It appears only to the self whose being it is. Thus other people cannot directly bear witness to my being-for-myself. Yet... this does not imply that they can regard me as simply a thing, a mere in-itself. It is normally impossible to take towards a living human being the kind of attitudes we take toward inanimate objects. Thus, when another person looks at me, a third kind of being arises in the world. This third kind of being Sartre calls 'being-for-others' (Levy, 2002:37).

There is a problem however. For Heidegger our "fundamental relation with other people is Mitsein ('being-with')". But not for Sartre for whom "we acquire our personal identity by means of the gaze of another" and not in self-reflection. "I am as the Other sees me" (Levy, 2002:38). This 'am-ness' is the 'being-for-others' which is however immediately reduced to a 'being-in-itself' (an object) by the Other's apprehension or recognition. And for Sartre, "To become an object for others is to become degraded; I, who was pure freedom [being-foritself], have become a mere thing". Of course I can turn the tables and objectify my objectifier but "either I am an object for a subject, or that subject is an object for me; never both at once... I can never... become the in-itself-for-itself". In the light of this "sinister dialectic of looking-at and being looked-at", Sartre concludes, "The essence of the relations between consciousnesses is not the Mitsein; it is conflict" or, as he put it in the play No Exit, "Hell is other people" (Levy, 2002:39). To return to Heidegger's 'equipment' then - for Sartre people do serve as 'equipment' but the relationship is a reciprocal one in which we oscillate in and out of either using, or being used by, other people.

Understandably enough not many people nowadays subscribe to Sartre's zero-sum, 'dog eat dog' view of human interaction although people do like to boast of the usefulness of their 'connections' and to flaunt their 'networks'. And as Nussbaum (2010:96) maintains: "Learning to see another human being not as a thing but as a full person is not an automatic event but an achievement that requires overcoming many obstacles" and not therefore something to be taken for granted. But the intention of delineating Sartre's schema here is not to persuade. It is rather to present a suggestive framework within which to pursue two lines of thought.

The first of these is that recent developments in the neurosciences show that Heidegger's question - "what will it do with me?" - can now legitimately be asked of the particular, as well as the universal, insofar as 'equipment' (and most especially IT 'gadgets'), is concerned. The second is a consideration of Jaron Lanier's (2010) You Are Not a Gadget in which he excoriates the hidden underpinnings of social networking. These two lines of enquiry cannot of course provide the last word on the potential impacts of the emerging social networking phenomenon, but they might provide some pointers as to how notions of human and social capital need to be revised in the light of it.

TD, 10(3), December 2014, pp. 380-392. 


\section{Convergent evolution}

Nicholas Carr (2010:44) divides technology into four rough categories. The first category extends our physical abilities and would include motor vehicles, lawnmowers and power drills. The second embraces those devices which sensitise or amplify our senses and includes telescopes, hearing aids, and radar. A third covers technology which bends nature to our wishes such as steroids, fertilizers and crop hybridisation. It is the fourth category, "intellectual technologies" which "support our mental powers", that he says "have the greatest and most lasting power over what and how we think". These technologies include clocks, books, maps and the Internet. As Carr puts it: "They are our most intimate tools, the ones we use for self-expression, for shaping personal and public identity, and for cultivating relations with others". Most important in this context is that these tools "work on our minds even as our minds work with them". In other words they serve to shape us. Paul Edwards (2010:28) in his study of widely dispersed infrastructures shows that, far from infrastructure necessarily being something physically huge and external to us, we may readily internalise it to the point where it is immanent within us. Describing the vast infrastructure underlying universal time he says: "Seconds before your morning alarm goes off, you awaken to an inner clock nearly as accurate as the one beside your bed: you have internalized the infrastructure". This is a reaction to an artificial 'event', say ' $6 \mathrm{am}$ ', that has no fixed existence in the sense that it happens' but which is merely a convention. It is an abstraction determined by a complex, dispersed apparatus. A further example is provided by the way a railway line or a main street may serve as a stratifying boundary that confers status, or a sense of belonging, depending upon which side of the demarcatory infrastructure one resides. Thus one may internalise that one was raised 'below the line' and develop a sense of self in accord with this - or use it as a stimulus to transcend one's conditioning.

But to return to Carr (2010:45) - "every intellectual technology... embodies an intellectual ethic, a set of assumptions about how the human mind works or should work". This ethic is often opaque to both the inventors and the users of the technology. Both of these parties are usually so taken up with maintaining or using the technology that they often fail to 'see the wood for the trees'. A topical example of an ethic at work is that, because it is feasible, one ought to have one's bank statements e-mailed to one instead of posted - this is ostensibly to save paper and, by extension, the environment. This is a classic instance of G.E. Moore's 'naturalistic fallacy' first identified by David Hume whereby an 'ought' is derived from an 'is'. Hume argued "that no description of the way the world is (facts) can tell us how we ought to behave (morality)" (Orr, 2011). And as Singer (2011:4) puts it, we cannot "identify normative truths with facts about the natural world, whether about our biological nature... or about what we would approve of under some set of specified conditions, or any other causal or psychological fact". Yet the mere fact that certain information is readily made available on the Internet ('ready-to-hand') can lead to tacit pressure being placed on individuals to subscribe to various feeds, or to familiarise themselves with the contents of various journals on an ongoing basis. This can easily result in a feeling of being driven by an array of 'oughts' imposed by an impersonal external agency one has no control over. A classic instance of this is the way time came to be internationally standardised, and punctuality inculcated as a virtue. The "widespread private use [of timepieces] laid the basis for time discipline as against time obedience... punctuality comes from within, not from without. It is the mechanical clock that made possible... a civilisation attentive to the passage of time, hence to productivity and performance" (Landes, 1983:7). According to Honoré (2004:23): "To teach workers the new time discipline demanded by modern capitalism, the ruling classes set about promoting 
punctuality as a civic duty and a moral virtue, while denigrating slowness and tardiness as cardinal sins". Turkle (2011:17) writes that: "Overwhelmed by the volume and velocity of our lives, we turn to technology to help us find time. But technology makes us busier than ever and ever more in search of retreat... we come to see our online life as life itself... the simplification of relationship is no longer a source of complaint. It becomes what we want. These seem the gathering clouds of a perfect storm".

The 'equipment' then, purely by dint of the fact that it is, comes to dictate a schedule for its own use. This is a reflection of the polarity in debates on technological progress. For instrumentalists "our instruments are the means we use to achieve our ends; they have no ends of their own" whereas for determinists (such as Karl Marx) technology "as an autonomous force outside man's control, has been the primary factor influencing the course of human history" (Carr, 2010:46). At first sight the instrumentalist view might seem to be the more sober one as we do surely choose whether to employ a particular tool or not, be it a motor vehicle or a pair of spectacles. And yet as Carr (2010:46) points out: "It strains belief to argue that we 'chose' to use maps and clocks (as if we might have chosen not to). It's even harder to accept that we 'chose' the myriad side effects of these technologies". Perhaps the difficulty can be accounted for by saying that the 'we' that chooses in the instrumentalist version functions at the level of individual agency in relation to a particular instantiation of technology whereas the 'we' that is effectively denied choice in the determinist version, and is therefore acted upon, is a matter of societal agency in relation to a universal phenomenon. In this case then our individual choices about whether to employ certain tools or not are downstream responses to some prior organic process that inserts itself into society simply by materialising. The particulars, the gadgets, are manufactured but the phenomenon that informs their instantiation is sui generis. Once again then we return to the questions suggested by Heidegger's notion of 'equipment' - what can I do with it and what might 'It' (writ large) do with me?

Technological determinism is overtly celebrated by Kevin Kelly (2010) in his What Technology Wants. For Kelly humanity, and what he terms the 'technium', are already well advanced on a process of 'convergent evolution' whereby the distinction between the two 'species' is becoming ever more blurred and they will eventually merge into a seamless and more highly evolved entity - perhaps a form of cyborg (and see Carlson, 2010). It is perhaps telling that we habitually refer to the brain's 'wiring'. This is presumably the ultimate form of Mitsein (Being-with), where two discrete domains of 'Being-withs' fuse, although Kelly cannot quite bring himself to confer life on the technium which he characterises instead as being 'near living' (for the moment). As he expresses it: "The technium is maturing into its own thing. Its sustaining network of self-reinforcing processes and parts have given it a noticeable measure of autonomy" (Kelly, 2010:12). The notion that technology will somehow come to reproduce itself and proliferate is a recurrent theme in this sort of determinism. Thus human beings are cast as "the sex organs of the machine world" whose role is to "fecundate" technology to the point where it becomes self-sustaining (McLuhan quoted in Carr, 2010:46). For Karl Marx humans become "appendages of the machine" (Kelly, 2010:194). For Kelly (2010:152), "The ever-thickening mix of existing technologies in a society creates a supersaturated matrix charged with restless potential". The sexual imagery of potency is inescapable here. The Economist (2011) carried a cover story about a new breed of 'printer' which could manufacture anything. In the case of the cover story it was a Stradivarius violin but in principle these 'printers' can reportedly produce any three-dimensional object given enough information and the appropriate 'inks' (plastics and resins). One obvious question 
which was not addressed, but which was left tacit, was whether these devices could in principle start 'printing' themselves as well as robots to tend their operations. The technology is known as 'additive manufacturing' and a basic 3D printer now costs less than did a laser printer in 1985. According to The Economist, "the technology is coming, and it is likely to disrupt every field it touches". And there are likely to be very few fields it does not touch. According to television news media it is now possible, in America, to 'print' new motor vehicles.

Unlike in Heidegger's day, when it was believed the brain was effectively 'cast in stone' once it had developed, we now know that it is not 'hard-wired' - that it is in fact "massively plastic" and that it is constantly in the process of reconfiguring itself (Carr, 2010:26), albeit at a slower tempo as we age. Blakeslee and Blakeslee (2007) also show how the brain 're-maps' itself to incorporate equipment that we use on a regular basis. This entails structural changes within the brain itself. The brain "incorporates your car, your bat, your racket, your pen, your chopsticks, your clothes... into your body's personal sense of self”. There are physical underpinnings to this. As Blakeslee and Blakeslee (2007:143) proceed to demonstrate: "it isn't pure wishy-washy mysticism to strive to 'become one with'... whatever tool it is you seek mastery with: It has a solid experiential and neuroscientific underpinning".

The Director of the Institute for the Future of the Mind at Oxford, Susan Greenfield (2010:48) writes that: "Screen technologies are neither evil nor miraculous in their effects on the human mind: rather, for every talent lost or diminished, another will be gained or enhanced. What is certain, however, is that our minds will change... the screen can change our brains and thus how we think". This is 'neuroplasticity' in action. But as Carr (2010:34) cautions, neuroplasticity "can end up locking us into rigid behaviours" including addictions. We experience a compulsion to keep our rewired circuitry active. Carr, for instance, relates how he became obsessively agitated about checking his e-mail once initiated into the technology. More ominously: "Plastic does not mean elastic... our neural loops don't snap back to their former state the way a rubber band does... and nothing says the new state has to be a desirable one" (Carr, 2010:34). For those who "value their virtual relationships and their avatars' well-being more than their own" (Blakeslee \& Blakeslee, 2007:160) or who spend several hours a week engaged in social networking (there are reports of people spending more time in Second Life than out of it), the 'internalisation of infrastructure' referred to earlier begins to take on new meaning (see for example Halpern 2014:22-24 on the "Internet of Things"). Web 2.0 afficionados (Web 2.0 dates from around 2005) typically involved in academia, content generation and social networking, sometimes report increasing difficulties with reading linearly. Instead they find themselves skimming, scrolling and 'cherry-picking'. Although they generally feel themselves to be more productive, they no longer have the patience to follow extended lines of argument (such as this one!) through to a conclusion preferring rather to scan for text-boxes and the like. In 2008 a survey conducted by the nGenera consultancy, on 6000 children who had grown up with the Internet, found that they "don't necessarily read a page from left to right and from top to bottom. They might instead skip around, scanning for pertinent information of interest” (Carr, 2010:9).

It would seem then that those who pride themselves on the capital represented by their virtual networks could find themselves possessed, or indeed physically modified, by those very networks. As Carr (2010:116) summarises:

One thing is very clear: if, knowing what we know today about the brain's plasticity, you were to set out to invent a medium that would rewire our mental circuits as quickly 
and thoroughly as possible, you would probably end up designing... the Internet [which] delivers precisely the kind of sensory and cognitive stimuli... that have been shown to result in strong and rapid alterations in brain circuits and functions... [it] turns us into lab rats constantly pressing levers to get tiny pellets of social or intellectual nourishment.

Is this necessarily a bad thing and what might it mean for social capital? Sartre was quoted above as saying that to be objectified is always a degradation, by which he means a loss of freedom - a determination imposed upon one by the Other. But what if one consents to be an object (cf. James, 2011)? Indeed what if one enjoys being an object under certain circumstances - high remuneration for example? What if one experiences it as a compliment that one should be chosen as an object by a subject? Is not this what celebrities aim for - to be an object to as many people as possible? Might one not freely present oneself as an object? When Sartre says that 'the Other' is constituted as a thing by the 'gaze' of the subject (a "transcendence transcended" in his terminology) we seem to hear echoes from the tourism literature where 'the Other', in the guise of 'the local', is 'commodified' and 'consumed' by the tourist gaze (Butcher, 2003) and this presumably not under duress.

\section{Social networking}

Is the voluntarily objectification described above not also the situation of the networker with hundreds or thousands of Facebook friends? But what are the opportunity costs (see Turkle, 2011:12) of cultivating and maintaining a thousand friends? Of having one's brain re-wired one way and not moulded in another? As per Watson (2010:162), "Email and cellphones are useful ways of enriching physical conversation and contact, but we are starting to use them to replace it... perhaps a question we should be asking ourselves... is not whether we can invent something but whether we should. What are the potential consequences of some of these inventions?" Since Watson posed this question it is now being claimed that actually talking on mobile phones (as opposed to texting) and even the use of e-mail are becoming passé (Behr, 2011; Turkle, 2011). What was once "better than nothing can become better than something - or better than anything" (Turkle, 2011:12). In the context of robotic companions, "When it comes to the perception of other minds, we are extremely gullible, bestowing agency on even the most inanimate of objects" (Lehrer, 2011). But as so many nowadays opine, at least robots are dependable and do not cheat, mess or die on one (Turkle, 2011).

The dynamics of Sartre's phenomenology are actually not nearly as convoluted, or as alien, as their unfamiliar terminology might suggest. It is his conclusion (that all is "conflict") that is difficult to accept because this is based on a dubious premise - that being an object to a subject is always a degradation. If we could allow for oscillating between subject and object roles without thereby feeling demeaned we could surely assent to Heidegger's Mitsein - the mode of 'being with'. In 1926 Heidegger wrote, "Even if we see the Other 'just standing around' [in other words 'ready-to-hand' like a piece of equipment], he is never apprehended as a human-Thing" (1962:156).

The Sartrean typology of Being can be usefully mapped onto a facility such as Facebook as a point of departure for where social networking might be headed. The Being-in-itself is simply the technology, the software system as well as whatever device the users employ to run it. Being-for-itself is the individual users' consciousness of themselves as mediated by their status, profiles, avatars and so forth. The Being-for-others is the Being-for-itself offered up by the user for scrutiny by 'the Other'. The problem for Lanier $(2010: 16)$ is that this is a less- 
than-human Being-for-itself - it is a "standardised presence" which means that being-foritself, which should be radically free, is coerced into making a thing of itself [a dataset] even prior to its objectification by the Facebook community. To add insult to injury, the Beingfor-itself is being recruited to a system where it is unwittingly being both locked-in and commodified by "antihuman software design" and the host system's need to provide a return on investment at some point. With roughly one billion users on Facebook alone that point is imminent. According to Lanier (2010:200) Facebook's users are not its customers - "stop calling yourself a user, you are being used". Facebook's real 'customers' are the prospective advertisers vying for aggregate information from its vast reservoir of users which is why Facebook is "evolving ways of goading [its users] into revealing more information" (Lanier, 2010:193 and see Chatfield, 2012 and Crawford, 2014:13).

This is of a piece with what Lanier (2010:71) means by "cybernetic totalism" which sounds very much like the technological determinism discussed earlier. He gives as an example a situation which might be familiar to anyone who has ever felt themselves being boxed in by a too-restrictive questionnaire: "On a typical social networking site, either you are designated to be in a couple or you are single (or you are in one of a few other predetermined states of being) - and that reduction of life is what gets broadcast between friends all the time. What is communicated between people eventually becomes their truth. Relationships take on the troubles of software engineering". These 'troubles' arise because these either/or binaries lie at the core of what is essentially poorly designed 'legacy'-type software. These reductivist dynamics have also been insightfully analysed by Morozov (2013:63-99) in a chapter entitled "So Open it Hurts" where he describes how people are unwittingly misrepresented online by processes known as data 'bouncing' and 'highlighting and shading'.

It is here that Sartre's 'degradation' makes its appearance. "What computerized analysis of all the country's school tests has done to education [disenfranchised teachers] is exactly what Facebook has done to friendships. In both cases life is turned into a database. Both degradations are based on the same philosophical mistake, which is the belief that computers can presently represent human thought or human relationships. These are things computers cannot currently do" [emphasis added] (Lanier, 2010:69; and see Nussbaum, 2010; Christian, 2011; Turkle, 2011; Chatfield, 2012 and Morozov, 2013). Given that Lanier was one of the pioneers of Virtual Reality (he coined the term) we may assume that he has privileged access to how technologically-induced reduction might work. Here then the tables are again turned and we find the infrastructure (Heidegger's 'equipment') coaxing its users into becoming objects who deliver up data (equipment being fed to sustain the overarching equipment) concerning themselves. As per Turkle (2011:xiv), "we seem determined to give human qualities to objects and content to treat each other as things".

\section{Conclusion}

This article has attempted to show that the social capital component of modern society is being subjected to unprecedented pressures and modification arising out of runaway technological developments most especially in the field of Information Technology. It has traced the trajectory, greatly facilitated by mobile telephony, towards the commodification of humans' personal attributes, and their conversion into 'things' and 'objects' for the delectation of an online consumer market.

Quite irrespective of the desirability or moral tenor of these developments, it stands to reason that any such seismic reconfiguration of society must, ipso facto, hold out unique challenges 
and opportunities. That many of these challenges have yet to be apprehended and articulated is consistent with the extreme unpredictability with which massively accelerated technological progress has imbued the social landscape.

\section{References}

Behr R (2011). Alone Together - review The Guardian [online]. 30 January. Retrieved from: http://www.guardian.co.uk/books/2011/jan/30/alone-together-sherry-turkle-review

Beevor A (1999). Stalingrad. London: Penguin.

Blakeslee S \& Blakeslee M (2007). The body has a mind of its own. New York: Random House.

Bohler-Muller N \& van der Merwe C (2011). The potential of social media to impact sociopolitical change on the African continent. Policy Brief. Pretoria: Africa Institute of South Africa (AISA).

Carlson RH (2010). Biology is technology: the promise, peril, and new business of engineering life. Cambridge (Mass.): Harvard University Press.

Carr N (2010). The shallows: How the Internet is changing the way we think, read and remember. London: Atlantic Books.

Chatfield T (2012). How to thrive in the digital age. London: Macmillan.

Christian B (2011). The most human human. New York: Doubleday.

Crawford K (2014). Social net worth. The New York Times Book Review. 16 November.

Economist. (2011). Print me a Stradivarius: how a new manufacturing technology will change the world. The Economist [online]. 10 February. Retrieved from: http://www.economist.com/node/18114327

Edwards PN (2010). A vast machine: Computer models, climate data, and the politics of global warming. Cambridge (Mass.): MIT Press.

Essoungou A-M (2011). A social media boom begins in Africa [online]. Retrieved from: http://www.ngopulse.org/article/social-media-boom-begins-africa

Florida R (2010). The great reset: how new ways of living and working drive post-crash prosperity. New York: HarperCollins.

Greenfield S (2010). Attention, please. Literary Review. September: 48-9.

Grootaert C, Narayan D, Nyhan-Jones V \& Woolcock M (2004). Measuring social capital: an integrated questionnaire. Washington: World Bank.

Halpern S (2014). The creepy new wave of the Internet. The New York Review of Books, Volume LXI, No. 18.

Heidegger M (1959). An introduction to metaphysics (trans. Manheim, R.). New Haven: Yale University Press.

Heidegger M (1962). Being and Time (trans. Macquarrie, J. \& Robinson, E.). Oxford: Basil Blackwell.

James EL (2011). Fifty shades of grey. London: Arrow Books.

Keeley B (2007). Human capital: How what you know shapes your life. Paris: OECD.

TD, 10(3), December 2014, pp. 380-392. 
Kelly K (2010). What technology wants. New York: Penguin.

Landes D (1983). Revolution in time: clocks and the making of the modern world. Cambridge (Mass.): Harvard Univeristy Press.

Lanier J (2010). You are not a gadget. London: Penguin.

Lehrer J (2011). We, Robots [online]. 21 January. Retrieved from: http://www.nytimes.com/2011/01/23/books/review/Lehrer-t.html

Levy N (2002). Sartre. Oxford: Oneworld Publications.

Lewis S (1922). Babbit. New York: Signet Classic.

Morozov E (2013). To save everything, click here. London: Allen Lane.

Orr HA (2011). The science of right or wrong [online]. The New York Review of Books. Retrieved from: http://www.nybooks.com/articles/archives/2011/may/12/scienceright-and-wrong/?pagination=false

Putnam RD (2000). Bowling alone: The collapse and revival of American community. New York: Simon \& Schuster.

Putnam RD \& Feldstein LM (2003). Better together: restoring the American community. New York: Simon \& Schuster.

Sartre J-P (1958). Being and nothingness (trans. Barnes, H.E.). London: Methuen \& Co.

Sen A (2006). Identity $\Xi^{2}$ violence: The illusion of destiny. London: Penguin.

Singer P (2011). One mountain. Times Literary Supplement. 20 May: 3-4.

Smith Z (2010). Generation why? [online]. The New York Review of Books. November 25. Retrieved from: http://www.nybooks.com/articles/archives/2010

Turkle S (2011). Alone together: why we expect more from technology and less from each other. New York: Basic Books.

Waterhouse R (1981). A Heidegger critique: a critical examination of the existential phenomenology of Martin Heidegger. Brighton: Harvester Press.

Watson R (2010). Future minds: how the digital age is changing our minds, why this matters and what we can do about it. London: Nicholas Brealy Publishing.

Willis K (2005). Theories and practices of development. Oxford: Routledge. 